\title{
ALTERASI DI SUMUR PENGEBORAN SMN-1 DAN SMN-2 DI DAERAH PANAS BUMI SUMANI, KABUPATEN SOLOK, PROPINSI SUMATERA BARAT
}

\section{ALTERATION ON SMN-1 AND SMN-2 DRILLING WELLS AT SUMANI GEOTHERMAL AREA, SOLOK REGENCY, WEST SUMATERA PROVINCE}

\author{
Sukaesih', Yuano Rezky ${ }^{1}$, Mega F. Rosana², Undang Mardiana ${ }^{2}$ \\ ${ }^{1}$ Pusat Sumber Daya Geologi, Jl. Soekarno-Hatta No. 444, Bandung 40254 \\ ${ }^{2}$ Fakultas Teknik Geologi UNPAD, Jl. Dipati Ukur No. 35, Bandung, 40132
}

\begin{abstract}
SARI
Daerah penelitian berada di lokasi sumur pengeboran SMN-1 dan lokasi sumur pengeboran SMN-2 berada di daerah panas bumi Sumani, Kabupaten Solok, Provinsi Sumatera Barat. Penelitian dilakukan untuk mengetahui tipe alterasi bawah permukaan dalam lingkungan sistem panas bumi daerah Sumani. Metode yang digunakan adalah melakukan deskripsi megaskopis, mikroskopis dan analisis karakterisasi terhadap batuan inti dari sumur SMN-1 (702 meter) dan SMN-2 (428 meter). Dilakukan juga pengukuran suhu pada sumur SMN-1 dan SMN-2 untuk mengetahui anomali gradien geothermal.
\end{abstract}

Berdasarkan hasil penelitian diketahui jenis-jenis mineral yang terbentuk dalam batuan bawah permukaan dan tipe ubahan serta korelasi zonasi alterasi bawah permukaan. Mineral ubahan yang dijumpai dalam batuan inti sumur SMN-1 terdiri dari; montmorilonit, smektit, sulfat, silika, halit, hematit, oksida vanadium, arsenat, karbonat, zeolit, ilit, pirofilit, klorit, muskovit, dan opal. Mineral ubahan yang terbentuk dalam sumur SMN-2 terdiri dari; kaolinit, montmorilonit, smektit, hematit, posfat, silikat, zeolit dan karbonat. Berdasarkan hasil pengelompokan mineral ubahan yang terbentuk dalam batuan bawah permukaan, sumur SMN-1 didominasi oleh tipe argilik (hingga kedalaman 100 meter) dan tipe propilitik (100-702 meter), sedangkan Sumur SMN-2 merupakan tipe ubahan argilik.

Gradien geothermal dari permukaan hingga kedalaman $700 \mathrm{~m}$ di sumur SMN-1 menunjukkan ratarata $12,86^{\circ} \mathrm{C} / 100$ meter, sedangkan di sumur SMN-2 diperoleh rata-rata $7^{\circ} \mathrm{C} / 100$ meter.

Kata kunci: Alterasi, argilik, propilitik, gradien panas bumi, Sumani

\section{ABSTRACT}

The study area is located at the site of SMN-1 well, drilled in the position of mT 677429 to 9915311 mU (UTM WGS 84, Zone 47s), at elevation of $544 \mathrm{~m}$. Drilling wells SMN-2 is located on the position of $m T 679184$ to $9915445 \mathrm{mU}$ (UTM WGS 84, Zone 47s) at elevation of $448 \mathrm{~m}$. This location is in the Sumani geothermal area, Solok Regency, West Sumatera Province. The study was conducted to determine the type of alteration in the subsurface environment of the Sumani geothermal system. The method consists of megascopic description, microscopic analysis and characterization of rock cores from SMN-1 and SMN-2 wells. Temperature measurements in the wells were carried out to determine the geothermal gradient anomalies.

The results revealed the kinds of minerals that formed in the subsurface rocks and alteration types. Mineral alteration encountered in the SMN-1 core consists of montmorillonite (smectite), sulfate, silica, halite, hematite, vanadium oxide, arsenic, carbonate, zeolite, illite, piropylite, chlorite, muscovite, and opal. Alteration minerals in SMN-2 core consist of Kaolinite, montmorillonite, smectite, hematite, phosphate, silicate, zeolite and carbonate. Based on grouping, type of alteration in the SMN-1 well is argillic type (down to 100 meters depth) and propylitic type (from 100 to 702 meters depth), while the $S M N-2$ well is argillic type of alteration.

Geothermal gradient from the surface to a depth of $700 \mathrm{~m}$ in the SMN-1 well showed the average of $12.86^{\circ} \mathrm{C} / 100$ meters, while in the SMN-2 well gained the average of $7^{\circ} \mathrm{C} / 100$ meters down to $428 \mathrm{~m}$ below the surface.

Keywords: Alteration, argilic, propylitic, geothermal gradient, Sumani. 


\section{MAKALAH ILMIAH}

\section{PENDAHULUAN}

Panasbumi merupakan suatu sistem geologi yang terdiri dari sumber panas, reservoir, lapisan penudung dan fluida panas. Dengan adanya interaksi yang komplek dalam sistem tersebut akan menghasilkan mineral-mineral sekunder yang dapat dijadikan sebagai salah satu indikator prospek tidaknya suati sistem panasbumi. Mineral primer cenderung terubah menjadi mineral sekunder akibat fulida panas (hidrotermal) tergantung pada suhu, permeabilitas, tekanan, komposisi cairan, komposisi awal batuan dan durasi aktivitas hidrotermal. Mineral ubahan hidrotermal dalam lingkungan panasbumi adalah albite, amphibole (actinolite), biotit, kalsit, klorit, kalsedon, epidot, fluorit, garnet, illite, K-feldspar (adularia), mordenit, sekunder oksida Fe- Ti, sulfida (pirit), titanit (sphene), wairakit, prehnit dan kuarsa, (John Lagat, 2015).

Penelitian berada di lokasi sumur pengeboran SMN-1 pada posisi 677429 mT s.d. $9915311 \mathrm{mU}$ (UTM WGS 84, zona 47S) dan lokasi sumur pengeboran SMN-2 pada posisi $679184 \mathrm{mT}$ s.d. $9915445 \mathrm{mU}$ Secara administratif daerah panasbumi Sumani berada di Kabupaten Solok Propinsi Sumatera Barat, berjarak sekitar 60 km dari kota Padang (Gambar 1.). Penelitian dilakukan untuk mengetahui mineral ubahan yang terbentuk pada batuan bawah permukaan, tipe ubahan dan zonasi - korelasi sumur SMN-1 dan SMN-2.

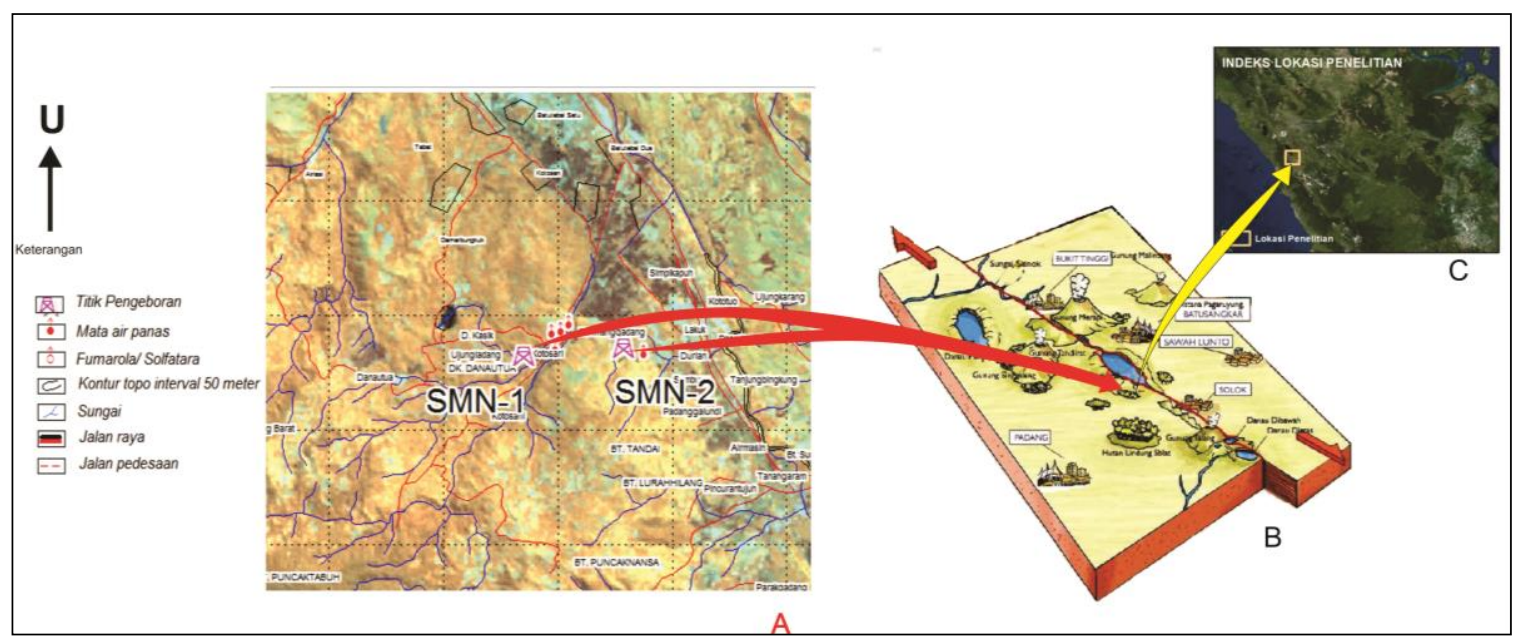

Gambar 1. Lokasi Penelitian di SMN-1 dan SMN-2

\section{GEOLOGI REGIONAL}

Daerah penelitian termasuk dalam lembar peta Solok, Sumatera Barat (Silitonga dan Kastowo, 1995) dan telah dilakukan penelitian geologi oleh Dudi dkk, PSDG 2011, disebutkan terdapat 12 jenis batuan, secara stratigrafi batuan berumur tua ke muda disusun oleh meta batugamping (PKg), batusabak (TRm), granit (TRig), andesit (Tia), vulkanik Tresier, endapan danau (Qed), lava Tinjau Laut (QTI), batuan piroklastik (QTap), endapan preatik (QeF), lava Cubadak (QCI), lava Gajah Dubalang (QGI), dan aluvium (Qal), (gambar 2).

Struktur geologi yang berkembang di daerah penelitian berarah baratlaut- tenggara mengikuti sesar Sumatera. Terbentuk sesar-sesar sekunder berupa rim kaldera, rim kawah.

\section{METODE PENELITIAN}

Metode yang dilakukan dalam penelitian, yaitu melakukan deskripsi megaskopis terhadap batuan inti hasll pengeboran SMN-1 hingga kedalaman 702 meter dan sumur SMN-2 hingga kedalaman 427 meter. Melakukan analisis petrografi terhadap batuan terpilih, melakukan karaketrisasi mineral ubahan menggunakan alat speccTERRA ${ }^{T M}$ melakukan pengolahan data serta interprtasi. 


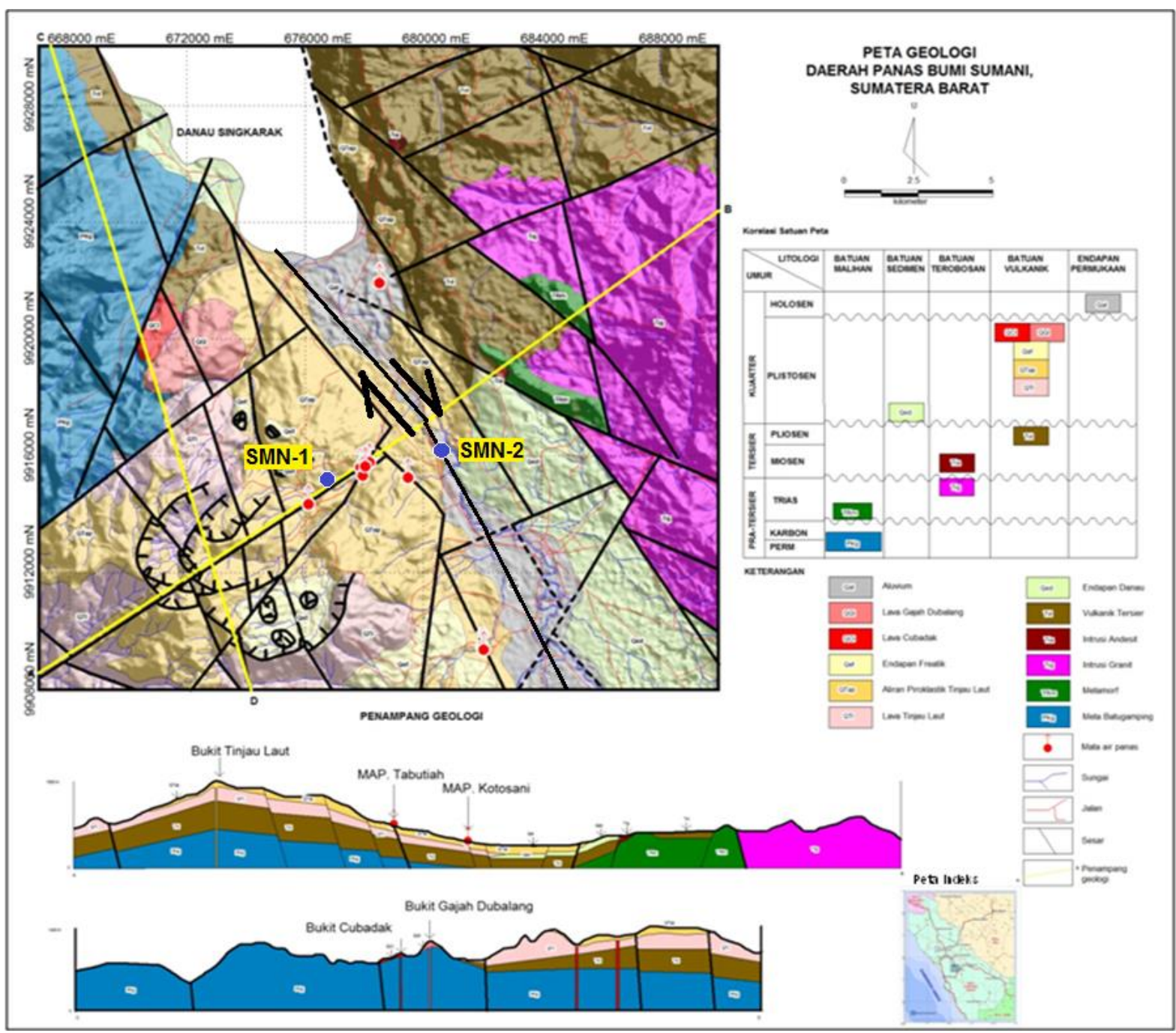

Gambar 2. Peta geologi daerah panasbumi Sumani, (Dudi, dkk, PSDG, 2011)

\section{METODE PENELITIAN}

Metode yang dilakukan dalam penelitian, yaitu melakukan deskripsi megaskopis terhadap batuan inti hasll pengeboran SMN-1 hingga kedalaman 702 meter dan sumur SMN-2 hingga kedalaman 427 meter. Melakukan analisis petrografi terhadap batuan terpilih, melakukan karaketrisasi mineral ubahan menggunakan alat speccTERRA ${ }^{T M}$ melakukan pengolahan data serta interprtasi.

\section{HASIL DAN PEMBAHASAN}

Litologi bawah permukaan berdasarkan deskripsi megaskopis batuan inti dari sumur SMN-1, dari bawah ke atas terdiri dari perselingan lava andesit piroksen, breksi andesit, breksi tuf, breksi andesit, lava, breksi lava tufaan, andesit, breksi andesit, breksi tuf, breksi andesit terubah, andesit, breksi lava andesit, andesit terubah, breksi andesit terubah, lava andesit terubah, breksi lava andesit terubah, lava andesit bagian atas berupa breksi tuf. Di sumur SMN-2 litologi hasil deskripsi megaskopis, dari bawah ke atas terdiri dari perselingan tuf, breksi andesit, breksi tuf, breksi andesit, andesit terkekarkan, breksi tuf, andesit terkekarkan, andesit, breksi tuf, andesit, batulempung sisipan batupasir, breksi andesit, andesit, breksi tuf, andesit dan endapan koluvium.

Hasil korelasi litologi bawah permukaan sumur SMN-1 dan SMN-2, dapat dilihat dalam gambar 3 . 


\section{MAKALAH ILMIAH}

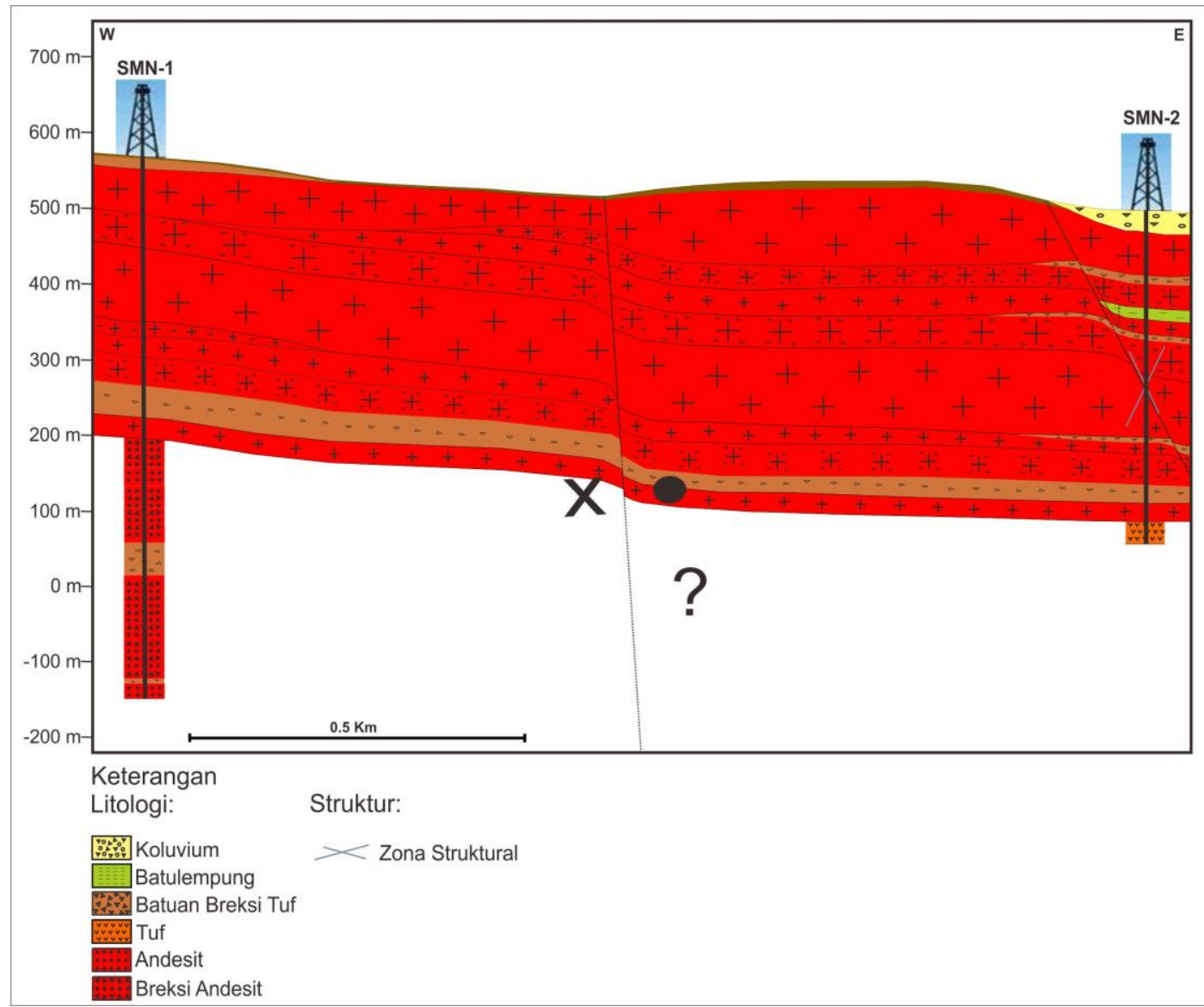

Gambar 3. Korelasi batuan bawah permukaan

Litostartigrafi bawah permukaan di daerah panasbumi Sumani didominasi oleh batuan vulkanik andesit berselingan dengan batuan piroklastik berupa tuf dan breksi tuf. Di sumur SMN-2 terdapat lapisan batulempung bersisipan batupasir, diinterpretasikan keberadaan lapisan batuan sedimen tersebut merupakan bagian dari endapan sedimen dari daerah graben.

Struktur geologi yang diamati di permukaan berupa breksiasi di sekitar mata air panas karimbia berupa batuan fragmen-fragmen lava andesit dalam masadasar milonit, (gambar 4).

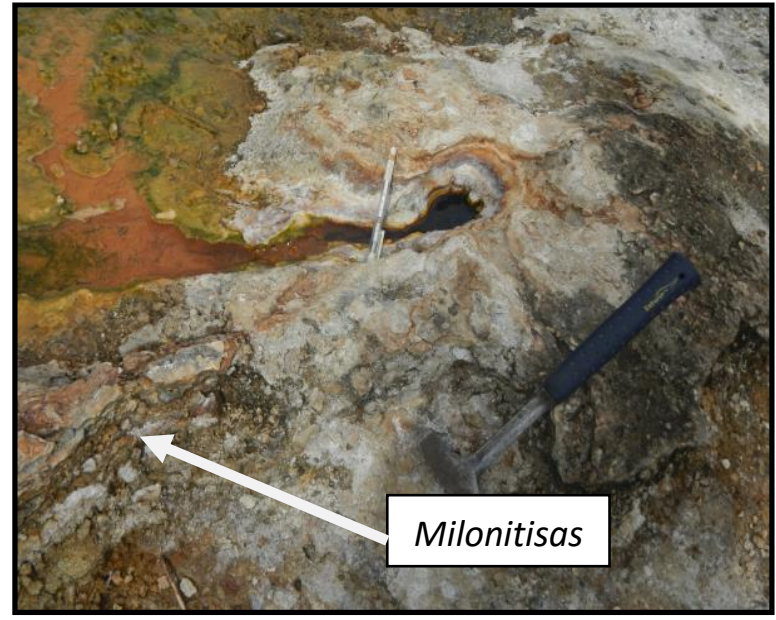

Gambar 4. Milonitisasi, dijumpai di mata air panas Karimbia, berarah timurlaut-baratdaya. 
Struktur geologi dapat diamati dari batuan inti di sumur SMN-1 pada kedalaman 236 m - 237 m, banyak dijumpai kekar-kekar gerus, rekahan dan breksiasi yang sudah terisi oleh mineral kalsit, mineral lempung, oksida besi, zeolit dan kuarsa sekunder.

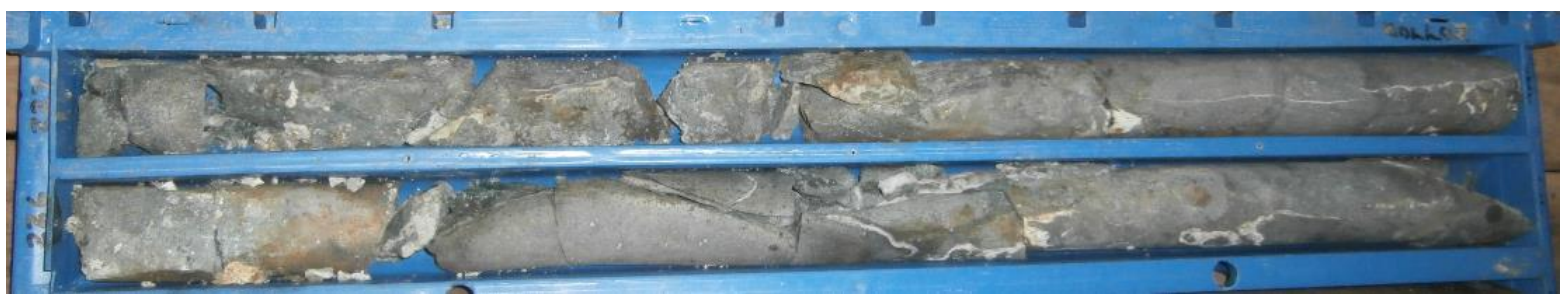

Gambar 5. Litologi high fractured pada kedalaman 236,00 m - 237,00 m, serta merupakan zona milonitisasi

Jenis mineral ubahan yang teridentifikasi pada batuan inti pada sumur SMN-1 hasil deskripsi mikroskopis dan karakterisasi menggunakan metode Infrared menggunakan instrumen speccTERRA $A^{T M}$ dapat dilihat dalam tabel 1.

Tabel 1. Kelompok mineral ubahan di sumur SMN-1

\begin{tabular}{|c|c|}
\hline Kode Sampel & Mineral Dominan \\
\hline SMN-1 7.85- 55.00 & $\begin{array}{l}\bullet \text { Montmorillonite (Smectite), } \bullet \text { Zeolite } \bullet \text { Phosphate, } \bullet \text { Sulfat, } \bullet \text { Silica } \\
\text { Hematite (Oxide), } \bullet \text { Halite, } \bullet \text { Vanadium Oxide } \bullet \text { Carbonate } \bullet \text { Arsenate, }\end{array}$ \\
\hline SMN-1 55.00-100,00 & $\begin{array}{l}\text {-Zeolite, } \bullet \text { Mottramite } \bullet \text { Silicate, } \bullet \text { Hematite } \bullet \text { Vanadium Oxide } \\
- \text { Phosphate } \bullet \text { Cyclosilicate } \bullet \text { Halite } \bullet \text { Carbonate } \bullet \text { Chlorite }\end{array}$ \\
\hline SMN-1 106.00-106.55 & $\begin{array}{l}- \text { Carbonate, } \bullet \text { Calcite } \bullet \text { Acmite } \bullet \text { Calcite, } \bullet \text { Mottramite, } \bullet \text { Almandine } \bullet \\
\text { Zeolite, } \bullet \text { Silicate } \bullet \text { Illite-smectite } \bullet \text { Montmorilonite, }, \bullet \text { Chlorite } \\
\bullet \text { Nontronite (Smectite) } \bullet \text { Muscovite } \bullet \text { Hematite, } \bullet \text { Opal (Silicate), } \\
\bullet \text { Halite, } \\
- \text { Pyrophyllite }\end{array}$ \\
\hline SMN-1 152.00-195.40 & $\begin{array}{l}\bullet \text { Silicate, } \bullet \text { Phospate (Anhydrous) } \bullet \text { Chlorite, } \bullet \text { Calcite, } \bullet \text { Halite } \\
(\text { Halide), } \bullet \text { Zeolite }, \bullet \text { Arsenate (Anhydrous) } \bullet \text { Illite } \\
\quad \text { Montmorillonite(Smectite) } \bullet \text { Sulfate } \bullet \text { Magnetite } \text { (Oxide) } \\
\text { Carbonate } \bullet \text { Silicate }\end{array}$ \\
\hline SMN-1 207.10-235.40 & $\bullet$ Zeolite, $\bullet$ Silicate, $\bullet$ Halite (Halide) \\
\hline SMN-1 235.00-294.00 & $\bullet$ Zeolite $\bullet$ Magnetite (Oxide), •Carbonate \\
\hline SMN-1 317.50-362.50 & $\begin{array}{l}- \text { Zeolite, } \bullet \text { Illite (Mica-Smectite) } \bullet \text { Percylite } \quad \text { (Halide), } \bullet \text { Silicate } \\
- \text { Chlorite (Chlorite), }\end{array}$ \\
\hline SMN -1 370.65-400.90 & 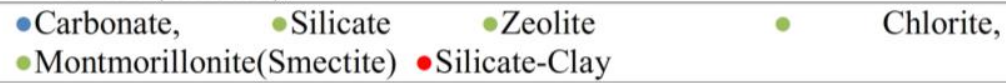 \\
\hline SMN -1 411.15-458.60 & $\begin{array}{l}- \text { Zeolite } \bullet \text { Smectite } \bullet \text { Calcite } \bullet \text { Carbonate, } \bullet \text { Silicate } \bullet \text { Montmorillonite } \\
- \text { Sulfate } \bullet \text { Smectite }\end{array}$ \\
\hline SMN -1 467.70-501.80 & $\bullet$ Chlorite $\bullet$ Carbonate, $\bullet$ Mottramite $\bullet$ Sulfate, $\bullet$ Smectite, $\bullet$ Zeolite, \\
\hline SMN -1 501.40-548.00 & $\begin{array}{l}\text { - Carbonate, } \bullet \text { Montmorillonite, } \bullet \text { Zeolite, } \bullet \text { Silicate-Clay } \\
\text { - Halite (Halide) } \bullet \text { Phosphate } \bullet \text { Silicate }\end{array}$ \\
\hline SMN-1 559.70-599-90 & $\begin{array}{l}- \text { Smectite, } \bullet \text { Calcite, } \bullet \text { Carbonate, } \bullet \text { Mottramite } \bullet \text { Biotite (Mica), } \bullet \\
\text { Opal (Silicate), } \bullet \text { Hematite } \bullet \text { Smectite, } \bullet \text { Hematite (Oxide), } \bullet \text { Muscovite } \\
- \text { Aragonite (Carbonate), } \bullet \text { Silicate }\end{array}$ \\
\hline SMN-1 600.35-657.20 & $\begin{array}{l}- \text { Muscovite } \bullet \text { Zeolite } \bullet \text { Phosphate (Anhydrous) } \bullet \text { Silicate } \\
- \text { Calcite, } \bullet \text { Carbonate } \bullet \text { Montmorillonite }\end{array}$ \\
\hline SMN-1 667.60-691.60 & $\begin{array}{l}- \text { Silicate-Clay } \bullet \text { Phosphate } \bullet \text { Halit } \bullet \text { Calcite, } \bullet \text { Carbonate, } \\
\text { (Silicate) } \bullet \text { Zeolite, } \bullet \text { Muscovite (Mica), }\end{array}$ \\
\hline
\end{tabular}




\section{MAKALAH ILMIAH}

Berdasarkan asosiasi dan intensitas ubahan mineral ubahan yang terbentuk dalam sumur SMN-1, dijumpai mineral ubahan yang dominan berupa kaolinit, montmorillonite, smectite, zeolit, asesoris phosphate (alunit) - silika dan sedikit karbonat dam klorit hingga kedalaman 100 meter, sehingga dapat dikelompokan tipe ubahan Smektit-Zeolit (Corbett \& Leach, 1998). Dari kedalaman 100 meter hingga 700 meter dijumpai mineral sekunder dominan klorit, karbonat, zeolit diikuti oleh mineral sekunder kriptokrstalin silika berupa opal, muskovit, dan mineral opak berupa magnetit berdasarkan Corbett dan Leach (1998) disetarakan dengan tipe ubahan pripilitik.

Hasil deskripsi megaskopis, mikroskopis dan dukungan data karakterisasi oleh instrumen speccTERRA $A^{T M}$, pada sumur pemboran SMN-2.

Tabel 2. Kelompok mineral ubahan dalam sumur SMN-2

\begin{tabular}{|c|c|}
\hline Kode Sampel & Mineral Dominan \\
\hline SMN-2 $49.00-49.25$ & -Kaolinit Montmorillonite (Smectite) $\bullet$ Phosphate •Borate \\
\hline SMN-2 52.50-52.55 & -Hematite $\bullet$ Montmorilonite (Smectite) $\bullet$ Oxide \\
\hline SMN-2 61.80-61.85 & -Carbonate $\bullet$ Phosphate, $\bullet$ Silicate \\
\hline SMN-2 73.70-73.85 & •Hematite (Oxide), •zeolite • Oxide \\
\hline SMN-2 81.90-82.00 & $\bullet$ Zeolite $\bullet$ Phosphate $\bullet$ Triphylite \\
\hline SMN-2 91.55-91.80 & -Carbonate $\bullet$ Silicate \\
\hline SMN-2 106.10-106.20 & -Zeolite $\bullet$ Silicate \\
\hline SMN-2 184.90-185.00 & $\bullet$ Zeolite, $\bullet$ Silicate \\
\hline SMN-2 194.70-194.75 & - Carbonate $\bullet$ Montmorilonite (Smectite) • Silicate \\
\hline SMN-2 204.00-204.05 & - Vanadate $\bullet$ Montmorilonite (Smectite) $\bullet$ Zeolite, \\
\hline SMN-2 214.70-214.80 & -Montmorilonite (Smectite) •Phosphate •Silicate \\
\hline SMN-2 223.00-223.25 & $\bullet$ Zeolite $\bullet$ Phosphate $\bullet$ Triphylite \\
\hline SMN-2 235.80-235.95 & $\bullet$ Zeolite, $\bullet$ Silicate $\bullet$ Halide \\
\hline SMN-2 244.70-244.80 & - Silicate $\bullet$ Acmite \\
\hline SMN-2 253.20-253.50 & - Borate $\bullet$ Silicate $\bullet$ Phosphate \\
\hline SMN-2 288,00-293,20 & -Clay Mineral • Carbonate \\
\hline SMN-2 350,20-350,30 & - Clay Mineral $\bullet$ Zeolite $\bullet$ Carbonate \\
\hline SMN-2 $397,80-397,90$ & - Clay Mineral •Zeolite \\
\hline SMN-2 419,00-419,05 & -Clay Mineral •Zeolite •Hematite (Oxide), \\
\hline
\end{tabular}

Pada sumur SMN-2 jenis mineral ubahan yang terbentuk dari permukaan hingga kedalaman 427 meter merupakan mineral ubahan dominan montmorilonit (smektit), zeolit diikuti mineral ubahan silikat, karbonat, hematit, phosfat, hematit (oksida) dan borat. Berdasarkan Corbett dan Leach (1998), disetarakan dengan tipe ubagan argilik.

Tipe ubahan di sumur SMN-1 dari permukaan hingga kedalaman 702 meter batuan sudah terubah hasil alterasi hidrotermal dan pengaruh air permukaan. Intensitas ubahan di sumur SMN-1, sebagai berikut :

Mineral lempung, (1- $29 \%$ dari total mineral), dijumpai hampir di semua kedalaman terdiri dari jenis smektit $\left((\mathrm{Na}, \mathrm{Ca})(\mathrm{Al}, \mathrm{Mg})_{6}(\mathrm{Si} 4 \mathrm{O} 10)_{3}(\mathrm{OH})_{6}-\mathrm{nH} 2 \mathrm{O}\right)$ dan montmorilonit $\left(\mathrm{M}_{\mathrm{x}}\left(\mathrm{Al}_{4-\mathrm{x}} \mathrm{Mg}_{\mathrm{x}}\right) \mathrm{Si}_{8} \mathrm{O}_{20}\right.$ $(\mathrm{OH})_{4}$. Kehadiran mineral lempung ini pada batuan vulkanik dan piroklastik berupa breksi tuf sebagai hasil proses argilitisasi terhadap mineral primer 
(plagioklas, piroksen, hornblende?) dan gelas vulkanik. Terbentuk dari permukaan hingga kealaman $650 \mathrm{~m}$. Umumnya terbentuk pada batuan vulkanik dengan intensitas ubahan $10 \%<$ hingga $<75 \%$. Smektit terbentuk pada kondisi fluida dengan $\mathrm{pH}$ 5-6 dengan temperatur pembentukan $50^{\circ}-150^{\circ} \mathrm{C}$. Montmorilonit terbentuk pada suhu $140^{\circ} \mathrm{C}$.

Alunit, $\mathrm{KAl}_{3}\left((\mathrm{OH})_{3}(\mathrm{SO} 4)_{2}(1-20 \%\right.$ dari total mineral), dijumpai pada kedalaman $50 \mathrm{~m}$, dan pada kedalaman $143 \mathrm{~m}$, berwarna putih, mudah hancur, terdapar dalam masadasar, pada kedalaman $143 \mathrm{~m}$ berasosiasi dengan karbonat dan kuarsa, bentuk kubik, hasil alterasi hidrotermal dengan batuan vulkanik asam-menengah. Deskripsi mikroskopis menunjukkan alunit yang terbentuk di kedalaman 50 meter berupa agregat-agregat halus, hal ini dapat diinterprtasikan sebagai mineral alterasi yang terbentuk hasil pelapukan ( pengaruh dominan air meteorik). Sedangkan pada kedalaman $427 \mathrm{~m}$, teramati berupa mineral dengan bentuk persegi, mengelompok, ini menunjukkan mineral alterasi terbentuk oleh prosen hidrotermal. Berdasarkan klasifikasi Browne, 1989 intensitas ubahan lemah sedang.

Kalsit, $\mathrm{CaCO}_{3}$ (1 - 40\% dari total mineral), dijumpai hampir di semua kedalaman mulai kedalaman $41 \mathrm{~m}$ hingga $700 \mathrm{~m}$. Secara megaskopis teridentifikasi berrwarna putih, jernih, hadir sebagai replacement, mengisi urat-urat halus dan rongga-rongga batuan. Kalsit terbentuk dengan kadar tinggi pada kedalaman 120 $\mathrm{m}$ dan $400 \mathrm{~m}$ hingga $580 \mathrm{~m}$, dominan sebagai pengisi rekalahan dan mengunah mineral-mineral primer.

Klorit, $\mathrm{Mg}_{5} \mathrm{Al}(\mathrm{OH})_{8} \mathrm{AlSi}_{3} \mathrm{O}_{10}(1-40 \%$ dari total mineral), dijumpai hampir di semua kedalaman mulai banyak hadir di kedalaman $93 \mathrm{~m}$, berwarna kehijauan, hadir sebagai replacement, mengisi uraturat halus dan rongga-rongga batuan.

Pirit, $\mathrm{FeS}_{2}(1-6 \%$ dari total mineral), dijumpai mulai di beberapa interval kedalaman dalam jumlah sedikit. Berwarna kuning, sedikit kecoklatan, berbentuk kubus. Kadang hadir pada bagian pinggir vein dan mengisi rongga/rekahan di batuan.

Oksida besi, $\mathrm{Fe}_{2} \mathrm{O}_{3}(1-30 \%$ dari total mineral), dijumpai sebagian besar di batuan vulkanik. Berwarna coklat, sedikit kekuningan, kemerahan. Kadang terdapat pada bagian pinggir fragmen dan mengisi rongga/rekahan di batuan. Hadir sebagai hasil ubahan dari mineral piroksen, plagioklas, dan gelas vulkanik.

Kuarsa sekunder, $\mathrm{SiO}_{2}(1-18 \%$ dari total mineral), hadir sebagai hasil ubahan dari masadasar dan fragmen, dijumpai di beberapa interval kedalaman. Mineral kuarsa tampak tidak berwarna, hadir mengisi rekahan berupa urat-urat halus dan mengisi rongga-rongga batuan. Kuarsa sekunder berupa kriptokristalin silika pada kedalaman $660 \mathrm{~m}$, mengisi rekahan berasosiasi dengan kalsit dan klorit.

Illit $\left.(\mathrm{OH})_{4} \cdot \mathrm{Al}_{4} \mathrm{Si}_{8} \mathrm{O}_{20} \cdot \mathrm{H}_{2} \mathrm{O}\right)$, $(2-6 \%$ dari total mineral), dijumpai di beberapa interval kedalaman dalam jumlah sedikit, berwarna putih. Hadir sebagai hasil ubahan dari masadasar dan fragmen.

Zeolit $\mathrm{H}_{\mathrm{x}}(\mathrm{Ca}, \mathrm{Na}) \mathrm{Al}_{\mathrm{x}}\left(\mathrm{SiO}_{2}\right)_{\mathrm{y}} \cdot \mathrm{mH}_{2} \mathrm{O}(1-5 \%$ dari total mineral), dijumpai hampir setiap kedalaman, terbentuk mulai pada kedalaman $45 \mathrm{~m}$ dengan jenisnya stilbit, diinterpretasikan sebagai ubahan dari gelas vulkanik dan sebagai pengisi veinlet bersama kuarsa dan kalsit mengisi rekahan, dan juga sebagai hasil ubahan dari masadasar.

Anhidrit, $\mathrm{CaSO}_{4},(1-5 \%$ dari total mineral), terbentuk pada kedalaman $143 \mathrm{~m}$ dengan kadar $<10 \%$.

Penentuan temperatur mineral ubahan yang terbentuk pada sumur SMN-1 mengacu kepada Reyes, 1990 dan Browne, 1999), tertera dalam tabel 3 dan 4. 


\section{MAKALAH ILMIAH}

Tabel 3. Kisaran temperatur mineral ubahan yang terbentuk dalam sumur SMN-1 pada zona argilik.

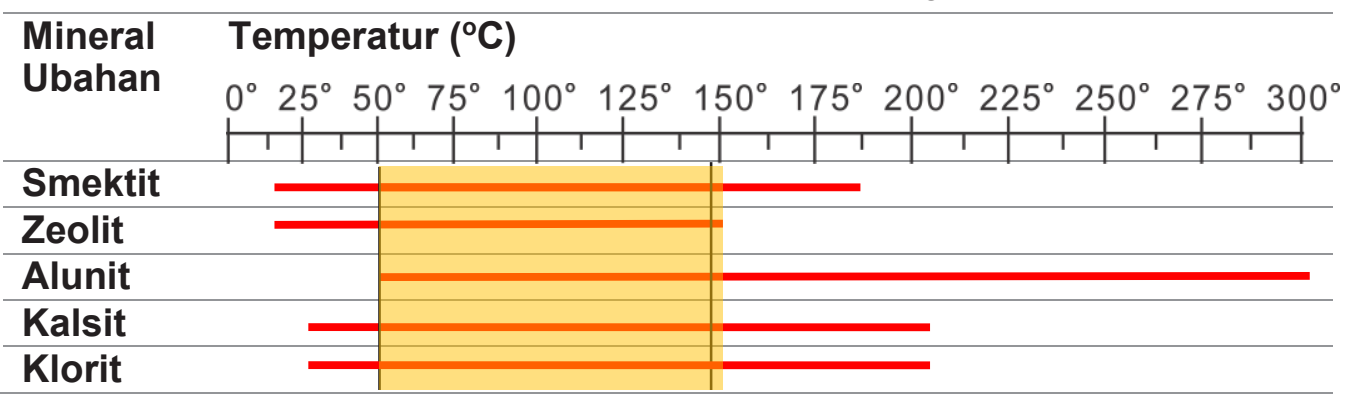

Tabel 4. Kisaran temperatur mineral ubahan yang terbentuk dalam sumur SMN-1 pada zona propilitik.

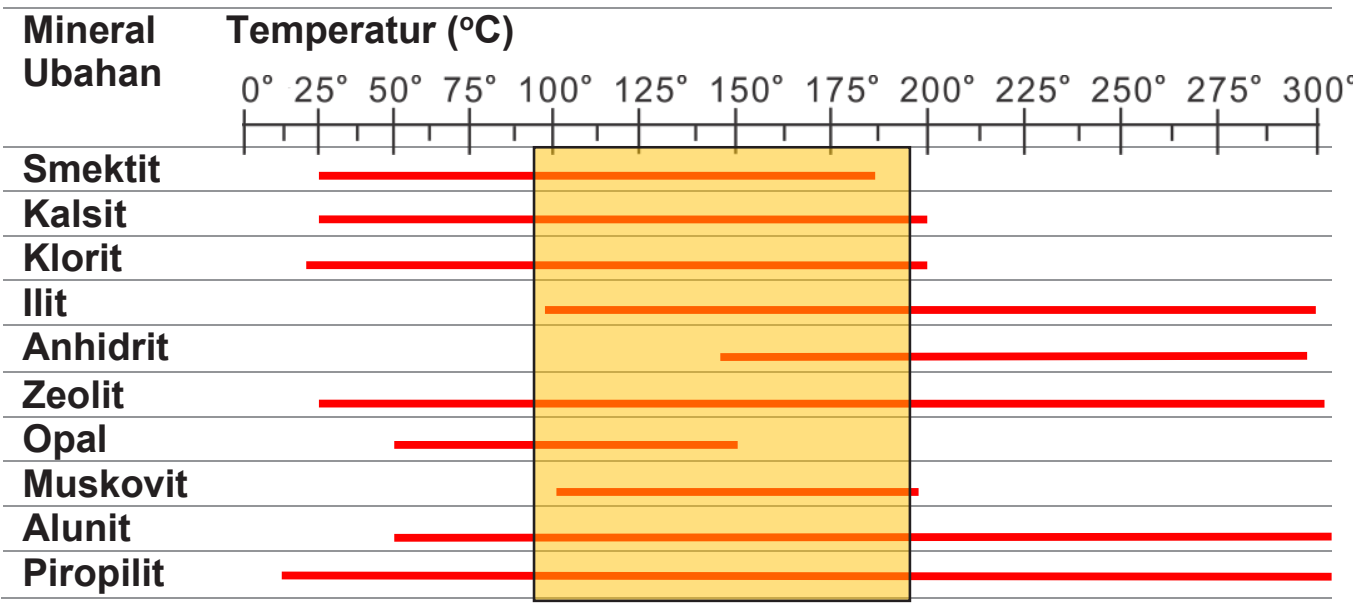

Berdasarkan temperatur pembentukan mineral ubahan dapat disimpulkan bahwa terdapat 2 zona pembentukan tipe ubahan, yaitu :

Zona ubahan tipe arglik, temperatur pembentukan mineral ubahan berkisar antara $50^{\circ} \mathrm{C}$ hingga $150^{\circ} \mathrm{C}$, himpunan mineral ubahan terdiri dari dominan smektit, zeolit, alunit, sedikit kalsit dan klorit.

Zona ubahan tipe propilitik, temperatur pembentukan mineral ubahan berkisar antara $100^{\circ} \mathrm{C}$ hingga $200^{\circ} \mathrm{C}$, himpunan mineral ubahan terdiri dari smektit, kalsit, klorit, ilit, anhidrit, zeolit, opal, muskovit, alunit dan propolit.

Tabel 5. Kisaran temperatur mineral ubahan yang terbentuk dalam sumur SMN-2

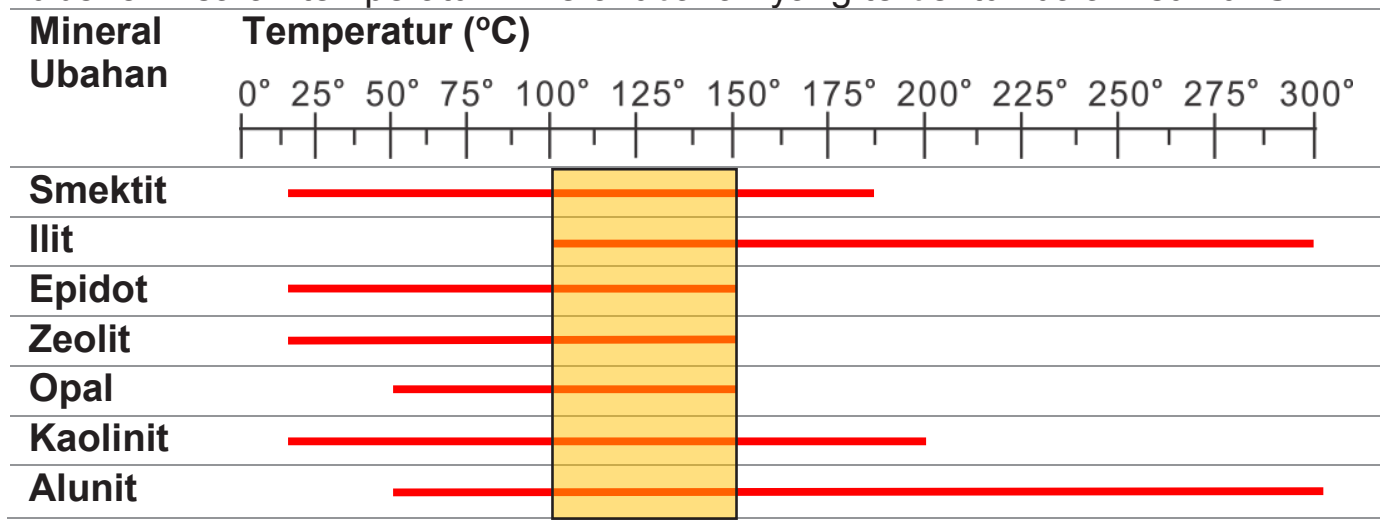


Distribusi mineral ubahan dan temperatur pembentukan mineral ubahan di sumurSMN-2 dijumpai mineral ubahan smektit, ilit, zeolit, opal, kaolinit dan alunit membentuk tipe zona argilik bertemperatur $100^{\circ} \mathrm{C}-150^{\circ} \mathrm{C}$.

Hasil karakterisasi mineral ubahan di sumur SMN-1 dan sumur SMN-2 dengan metode Infrared Mineral Analyzer, menunjukkan tiap-tiap litologi telah mengalami ubahan hidrotermal dengan distribusi mineral ubahan, kondisi pembentukan, tipe ubahan, zonasi ubahan dan paleotemperatur serta temperatur saat ini tercantum dalam tabel 6 dan 7 .

Zonasi ubahan bawah permukaan di sumur SMN-1 dari permukaan hingga kedalaman 100 meter merupakan tipe ubahan argilik, dari kedalaman $100 \mathrm{~m} \mathrm{s.d}$ 702 m merupakan tipe ubahan propilitik, dominan disusun oleh mineral ubahan kalsit, klorit dan zeolit dengan intensitas ubahan $>75 \%$.

Tabel 6. Distribusi mineral ubahan, kondisi pembentukan dan paleotemperatur sumur SMN-1

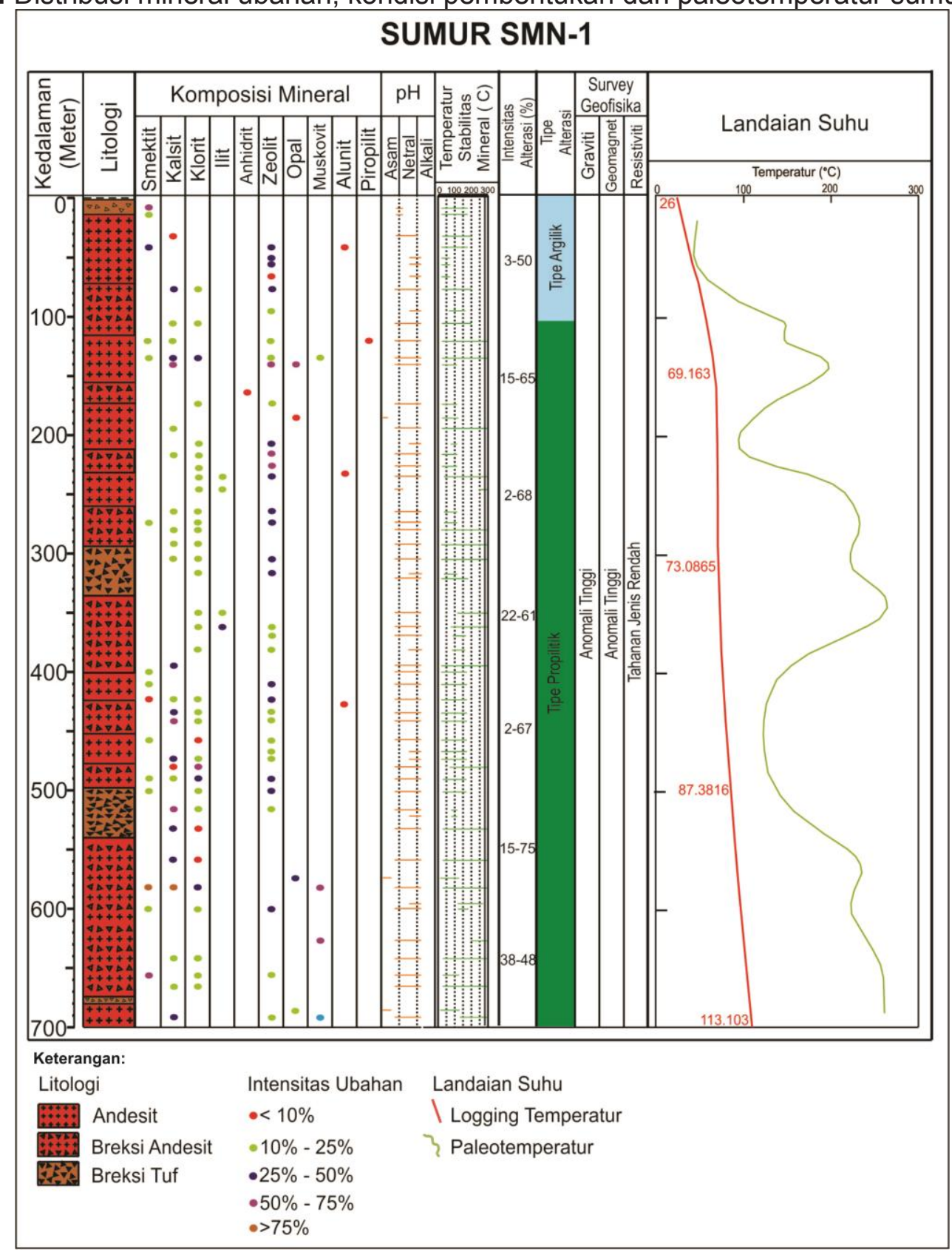




\section{MAKALAH ILMIAH}

Zona alterasi argilik dicirikan dengan melimpahnya distribusi mineral lempung smektit yang disertai dengan kehadiran mineral kalsit dan zeolit (kabazit, stilbit) terbentuk pada kisaran temperatur $50^{\circ}$ $140^{\circ}$ C. Terdapat pada sumur SMN-1 dengan ketebalan berkisar $100 \mathrm{~m}$. Zona alterasi propilitik yang dicirikan dengan melimpahnya distribusi mineral klorit, zeolit (kabazit, mordenit, stilbit, heulandit, laumontit) terbentuk pada kisaran temperatur $100^{\circ}-220^{\circ}$ C. Terdapat pada sumur SMN-1 dengan ketebalan mencapai $702 \mathrm{~m}$.

Tabel 7. Distribusi mineral ubahan, intensitas ubahan,

kodisi lingkungan, tipe serta paleotemperatur dan temperatur saat ini di sumur SMN-2.

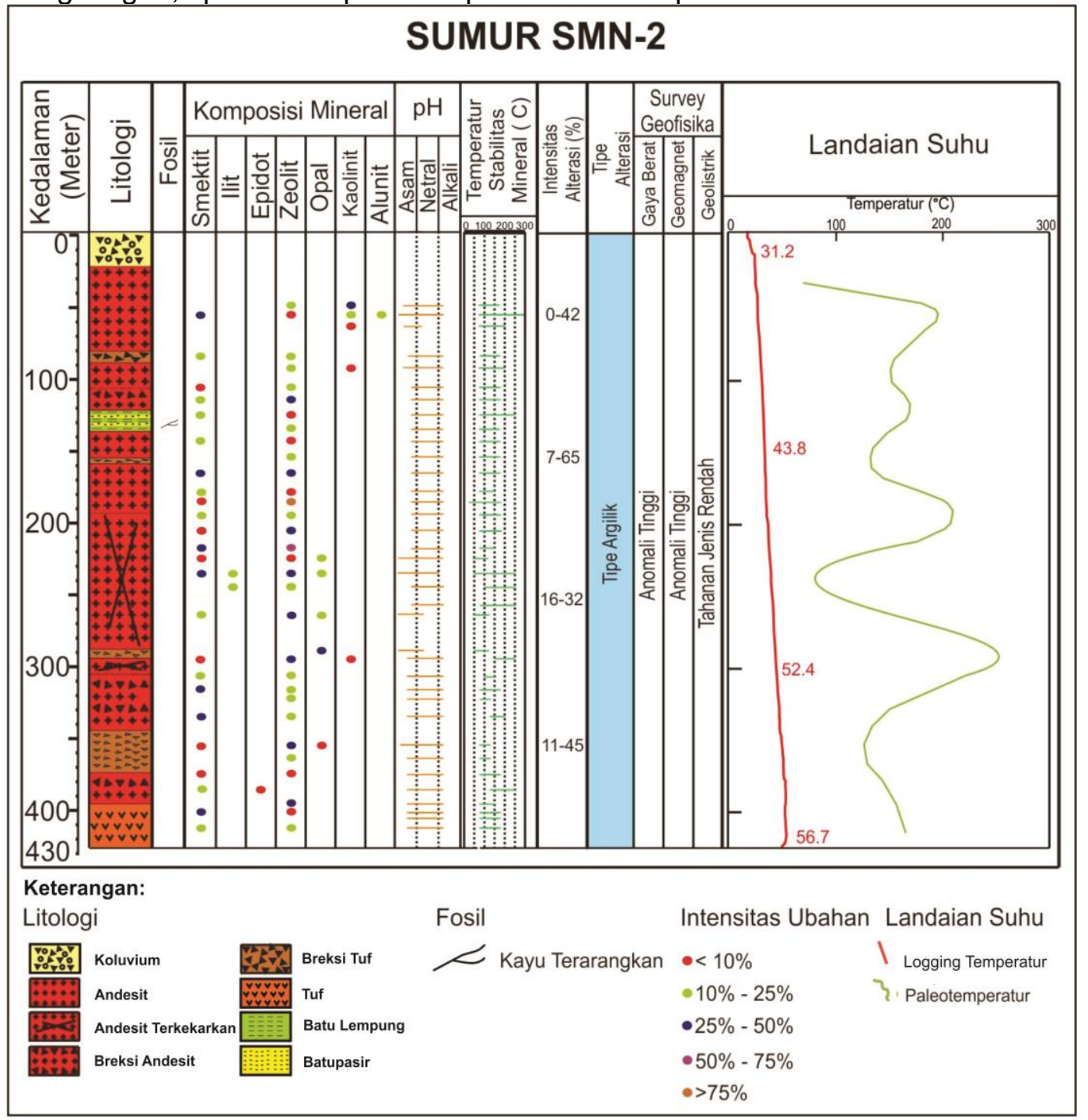

Distribusi mineral ubahan, sumur SMN-2 menunjukkan bahwa zonasi yang terbentuk terdiri dari zona alterasi SmektitZeolit. Mineral sekunder yang terbentuk adalah smektit, ilit, epidot, zeolit, opal, kaolinit dan alunit.

Smektit, hadir hampir dalam tiap kedalaman dari kadar $<10 \%$ hingga $25 \%$ $50 \%$ terdapat pada batuan vulkanik maupun dalam batuan piroklastik, banyak terakumulasi pada zona batuan terkekarkan pada kedalaman $150 \mathrm{~m}$ hingga $250 \mathrm{~m}$.

Illit, dijumpai pada kedalaman $240 \mathrm{~m}$ hingga $250 \mathrm{~m}$ dengan kadar rendah sedang $10 \%-25 \%$.

Epidot, dijumpai pada kedalaman 390 m 
kadarnya $<10 \%$, diinterprtasikan sebagai fosil mineral alterasi yang terbawa dalam fragmen batuan.

Zeolit, jenisnya khabazit dan mordenit, hadir hampir dalam setiap kedalaman dari kedalaman $50 \mathrm{~m}$ hingga $427 \mathrm{~m}$, dengan kadar bervariasi dari $<10 \%$ hingga $50 \%$ s.d $75 \%$.

Opal, terbentuk mulai dari kedalaman 220 $\mathrm{m}$ hingga kedalaman $350 \mathrm{~m}$ kadarnya $10 \%$ hingga kisaran $20 \%$ s.d $50 \%$, umumnya terbentuk pada zona terkekarkan.

Kaolinit, terbentuk pada kedalaman yang dangkal yaitu $50 \mathrm{~m}$ hingga $100 \mathrm{~m}$, diinterprtasikan sebagai mineral sekunder terbentuk dengan proses pelapukan (dominan air meteorik).

Alunit, terbentuk pada kedalaman $50 \mathrm{~m}$, dengan kadar $<10 \%$, diinterprtasikan terbentuk dalam proses pelapukan.

Litologi di sumur SMN-2 hingga kedalaman 427 dijumpai mineral ubahan smektit, ilit, epidot, zeolit, opal, kaolinit, alunit, terbentuk pada kondisi lingkungan $\mathrm{pH}$ asam hingga netral, membentuk tipe ubahan argilik.

Zona alterasi argilik dicirikan dengan melimpahnya distribusi mineral lempung smektit yang disertai dengan kehadiran mineral kalsit dan zeolit (kabazit, stilbit) terbentuk pada kisaran temperatur $50^{\circ}-140^{\circ} \mathrm{C}$. Terdapat pada sumur SMN-1 dengan ketebalan berkisar $100 \mathrm{~m}$ yang menebal hingga kedalaman akhir sumur SMN-2 pada kedalaman $427 \mathrm{~m}$.

Zona alterasi propilitik yang dicirikan dengan melimpahnya distribusi mineral klorit, zeolit (kabazit, mordenit, stilbit, heulandit, laumontit) terbentuk pada kisaran temperatur $100^{\circ}-220^{\circ} \mathrm{C}$. Terdapat pada sumur $\mathrm{SMN}-1$ dengan ketebalan mencapai $600 \mathrm{~m}$, dimana indikasi keberadaan zona alterasi ini tidak ditemukan pada sumur SMN-2.

Korelasi zona ubahan SMN-1 dan SMN-2 tergambar dalam gambar 6, zona ubahan argilik dicirikan dengan melimpahnya distribusi mineral lempung smektit yang disertai dengan kehadiran mineral kalsit dan zeolit (kabazit, stilbit) terbentuk pada kisaran temperatur $50^{\circ}-140^{\circ} \mathrm{C}$. Terdapat pada sumur SMN-1 dengan ketebalan berkisar $100 \mathrm{~m}$ yang menebal hingga kedalaman akhir sumur SMN-2 pada kedalaman $427 \mathrm{~m}$. Zona alterasi propilitik yang dicirikan dengan melimpahnya distribusi mineral klorit, zeolit (kabazit, mordenit, stilbit, heulandit, laumontit) terbentuk pada kisaran temperatur $100^{\circ}$ $220^{\circ}$ C. Terdapat pada sumur SMN-1 dengan ketebalan mencapai $600 \mathrm{~m}$, dimana indikasi keberadaan zona alterasi ini tidak ditemukan pada sumur SMN-2.

Korelasi zona ubahan sumur SMN-1 dan sumur SMN-2 digambarkan pada gambar 6, berikut : 


\section{MAKALAH ILMIAH}

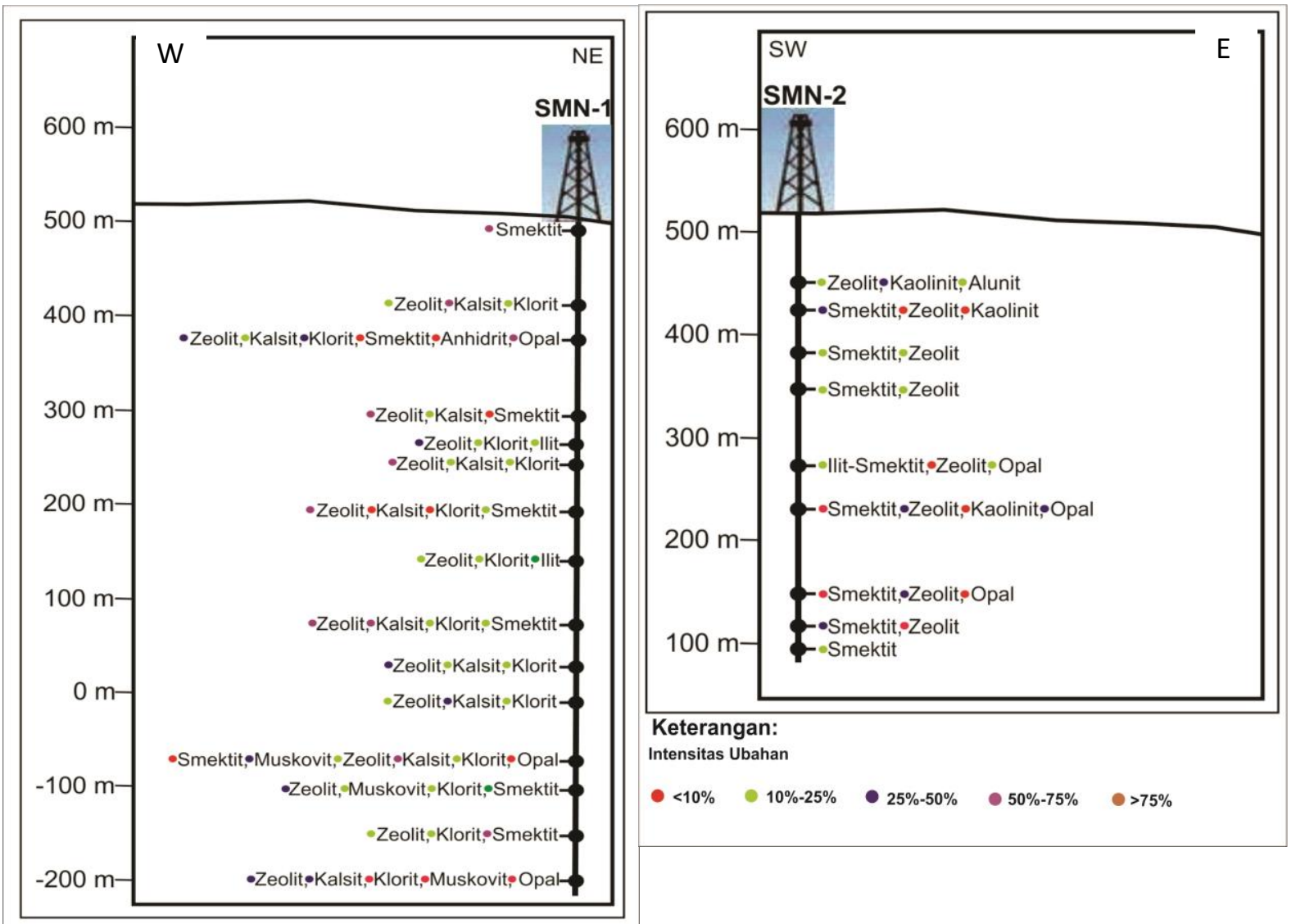

Keterangan:

Intensitas Ubahan

- $<10 \%$ - $10 \%-25 \% \quad \bullet 25 \%-50 \% \quad \longrightarrow 50 \%-75 \% \quad \rightarrow 75 \%$

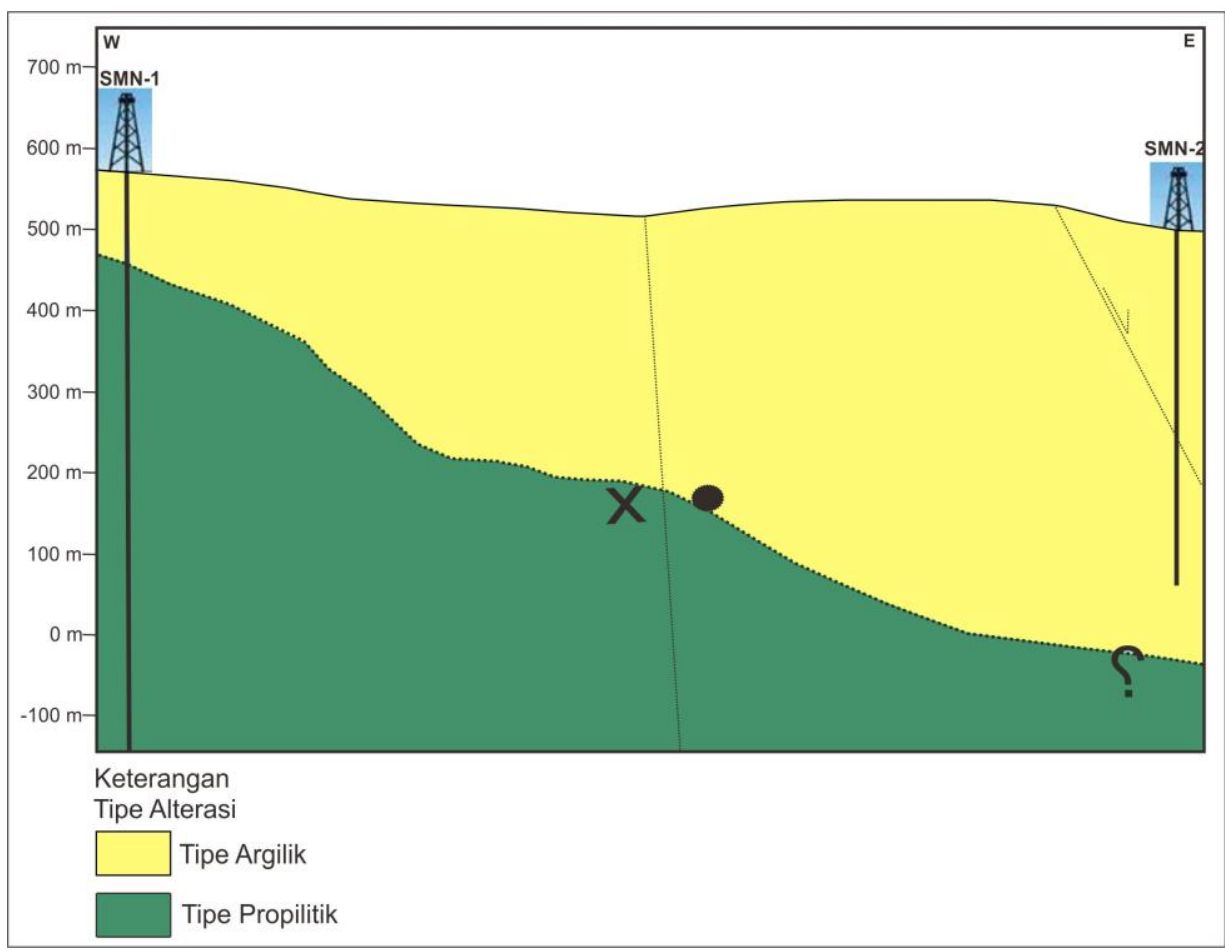

Gambar 6. Korelasi zona ubahan sumur SMN-1 dan sumur SMN-2, Daerah Panasbumi Sumani, Kab. Solok, Prov. Sumatera Barat. 


\section{KESIMPULAN}

Di Daerah Panasbumi Sumani, stratigrafi bawah permukaan berdasarkan batuan inti hasil pengeboran terdapat ada 4 jenis batuan, yaitu :

a. Breksi Tuf

b. Breksi Andesit

c. Batulempung sisispan batupasir

d. Andesit

Himpunan mineral ubahan yang terbentuk di batuan bawah permukaan terdiri dari zeolit, klorit, kalsit, alunit, ilit, smektit, kaolinit, kuarsa (kalsedon), montmorilonit dan anhidrit. Mineral zeolit, klorit, kalsit, alunit dan smektit terbentuk pada kondisi $\mathrm{pH}$ asam hingga netral temperatur rendah $50^{\circ} \mathrm{C}$ s.d $140^{\circ} \mathrm{C}$, sedangkan ilit dan serisit terbentuk pada lingkungan $\mathrm{pH}$ asam pada temperatur $200^{\circ} \mathrm{C}$ s.d $300^{\circ} \mathrm{C}$.

Asosiasi mineral ubahan pada sumur SMN-1 membentuk zonasi alterasi yaitu zonasi alterasi tipe argilik dari permukaan hingga kedalaman $100 \mathrm{~m}$ dan zonasi alterasi tipe propilitik dari kedalaman 100 $\mathrm{m}$ hingga kedalaman $702 \mathrm{~m}$. Mineral ubahan pada sumur SMN-2 membentuk zonasi alterasi tipe argilik hingga kedalaman 427 meter.

\section{UCAPAN TERIMAKASIH}

Terimakasih disampaikan kepada Tim Editor dan Tim publikasi Buletin Pusat Sumber Daya Geologi yang telah membantu menyempurnakan dan dimuatnya makalah ini.

\section{DAFTAR PUSTAKA}

Browne, P.R.L. 1999. Hydrothermal Alteration. Lecture Handout. The University of Auckland, Geothermal Institute

Corbett \& Leach. 1997. Southwest Pasific Rim Gold-Copper System: Structure, Alteration and Mineralization. Short Course Manual. USA: Society of EconomicsGeologist, Inc
Ellis, A.J. dan Mahon, W.A.J. 1977. Chemistry and Geothermal Systems, New York: Academic Press.

Guilbert, J.M. dan Park, C.F., JR.1986. The Geology of OreDeposit. New York, Oxford: W.H. Freeman.

Henley, R.W. dan Ellis A.J. 1983. Geothermal Systems Ancientsand Modern: A GeochemicalReview. Amsterdam:ElsevierScientificPublish ing Company

Lagat, J, 2015, Hydrothermal Alteration Mineralogy in Geothermal Fields with Case Examples From Olkario Domes Geothermal Field, Kenya.

Mbia P.K, dkk. 2015. Sub-surfaceGeology, PetrologyandHydrothermalAlteration of the Menengai Geothermal Field, Kenya: Case Study of Wells MW-02, MW-04 malCongress 2015

Dudi H. 2011. Peta Geologi Daerah Sumani. Bandung: Pusat Sumber Daya Geologi.

Anonim. 2011, a. Penyelidikan Geofisika Terpadu Daerah Panas Bumi Sumani. Bandung: Pusat Sumber Daya Geologi.

Anonim. 2011, b. Survei Aliran Panas (Heat Flow) Daerah Panas Bumi Sumani. Bandung: Pusat Sumber Daya Geologi.

Anonim. 2011, c. Survei Terpadu, Geologi, Geokimia dan Geofisika Daerah Panas Bumi Sumani. Bandung: Pusat Sumber Daya Geologi.

Reyes, A.G. (2000).Petrologyand mineral alterationinhydrothermalsystem: FromDiagenesistovolcaniccatastroph es. Institute of Geologicaland Nuclear Sciences., 10-17

Rybach, L dan Muffler P. 1981. Geothermal Systems: PriciplesandCaseHistories. Haboken: John Wileyand Sons 


\section{MAKALAH ILMIAH}

Saptadji, Nenny Miryani. 2009. Karakterisasi Reservoir Panas Bumi. Training Advanced Geothermal Engineering, 6 - 17 Juli 2009. Bandung: Institut Teknologi Bandung

Silitonga, P.H., dan Kastowo. 1995. Peta Geologi Lembar Solok, Sumatera. Bandung: Pusat Penelitian dan Pengembangan Geologi

$$
\begin{array}{ll}
\text { Diterima } & : 4 \text { September } 2015 \\
\text { Direvisi } & : 1 \text { Oktober } 2015 \\
\text { Disetujui } & : 17 \text { November } 2015
\end{array}
$$

